\title{
Cassava stillage and its anaerobic fermentation liquid as external carbon sources in biological nutrient removal*
}

\author{
Fan BU, Xiang HU ${ }^{\dagger *}$, Li XIE, Qi ZHOU \\ (State Key Laboratory of Pollution Control and Resource Reuse, College of Environmental Science and Engineering, \\ Tongii University, Shanghai 200092, China) \\ †E-mail: xiangh1215@outlook.com \\ Received Apr. 17, 2014; Revision accepted Dec. 10, 2014; Crosschecked Mar. 10, 2015
}

\begin{abstract}
The aim of this study was to investigate the effects of one kind of food industry effluent, cassava stillage and its anaerobic fermentation liquid, on biological nutrient removal (BNR) from municipal wastewater in anaerobicanoxic-aerobic sequencing batch reactors (SBRs). Experiments were carried out with cassava stillage supernatant and its anaerobic fermentation liquid, and one pure compound (sodium acetate) served as an external carbon source. Cyclic studies indicated that the cassava by-products not only affected the transformation of nitrogen, phosphorus, poly- $\beta$-hydroxyalkanoates (PHAs), and glycogen in the BNR process, but also resulted in higher removal efficiencies for phosphorus and nitrogen compared with sodium acetate. Furthermore, assays for phosphorus accumulating organisms (PAOs) and denitrifying phosphorus accumulating organisms (DPAOs) demonstrated that the proportion of DPAOs to PAOs reached $62.6 \%$ (Day 86 ) and $61.8 \%$ (Day 65) when using cassava stillage and its anaerobic fermentation liquid, respectively, as the external carbon source. In addition, the nitrate utilization rates (NURs) of the cassava by-products were in the range of $5.49-5.99 \mathrm{~g} \mathrm{~N} /(\mathrm{kg}$ MLVSS $\mathrm{h}$ ) (MLVSS is mixed liquor volatile suspended solids) and 6.63-6.81 g N/(kg MLVSS.h), respectively. The improvement in BNR performance and the reduction in the amount of cassava stillage to be treated in-situ make cassava stillage and its anaerobic fermentation liquid attractive alternatives to sodium acetate as external carbon sources for BNR processes.
\end{abstract}

Key words: Biological nutrient removal (BNR), Denitrification, Enhanced biological phosphorus removal (EBPR), External carbon source

doi: $10.1631 /$ jzus.B1400106

Document code: A

CLC number: X52

\section{Introduction}

Due to increasingly stringent limits for nitrogen and phosphorus removal, the amount of organic compounds in influent wastewater often is not sufficient for efficient denitrification and enhanced biological phosphorus removal (EBPR) in biological nutrient removal (BNR) systems. In such cases, spe-

\footnotetext{
${ }^{\ddagger}$ Corresponding author

* Project supported by the National Water Pollution Control and Management of Major Special Science and Technology Foundation (No. 2011ZX07303-001), China

(iD) ORCID: Xiang HU, http://orcid.org/0000-0002-1205-9611

(c) Zhejiang University and Springer-Verlag Berlin Heidelberg 2015
}

cific available commercial compounds ("conventional" external carbon sources), such as methanol, ethanol, acetic acid, and sodium acetate, are usually added to improve the overall BNR performance and obtain low effluent levels for nitrogen and phosphorus. However, these commercial external carbon sources are expensive and usually require acclimation periods. Such attributes do not recommend their application in full-scale plants. On the other hand, in many cases, the problem of high costs of commercial organic compounds can be overcome if industrial wastewater, such as brewery wastewater, is readily accessible (Henze et al., 1995). Various industrial by-products or waste materials have recently received 
more attention as "alternative", cost-effective external carbon sources for denitrification (Makinia et al., 2012). Among these materials, food industry effluents stand out as being potential alternatives for "conventional" external carbon sources due to their high $\mathrm{C} / \mathrm{N}$ ratios and high content of readily biodegradable organic compounds (Lim et al., 2000; Cappai et al., 2004; Quan et al., 2005; Sage et al., 2006; Swinarski et al., 2009a). However, the use of food industry effluents may result in some operating problems, including variation in quality and quantity resulting from their seasonal production cycles.

Different food industry effluents as external carbon sources have been shown to enhance denitrification in BNR systems. Swinarski et al. (2009b) investigated three different types of industrial wastewater (effluents from a distillery, brewery, and fish-pickling factory, respectively) on the denitrification capability of process biomass originating from a full-scale BNR plant in northern Poland. These three food industry effluents were characterized by a high content of easily biodegradable chemical oxygen demand (COD) (33.7\%-88.5\% of the total COD) and low nutrient concentrations (COD/total nitrogen (TN) ratios in the range of 15.1-80.6). The observed single nitrate utilization rates (NURs) for three industrial wastewaters ranged from 4.8 to $5.1 \mathrm{mg} \mathrm{N} /(\mathrm{g} \mathrm{VSS} \cdot \mathrm{h})$, 2.4 to $6.0 \mathrm{mg} \mathrm{N} /(\mathrm{g} \mathrm{VSS} \cdot \mathrm{h})$, and 4.0 to $6.0 \mathrm{mg} \mathrm{N} /$ (g VSS·h) (VSS is volatile suspended solids), respectively, compared with the rates associated with the use of readily biodegradable COD in settled wastewater. Quan et al. (2005) recommended hydrolyzed molasses as an economical and effective external carbon source for nitrogen removal. They found that with hydrolyzed molasses the denitrification rate was $2.9-3.6 \mathrm{mg} \mathrm{N} /(\mathrm{g}$ VSS$\cdot \mathrm{h})$ and that a higher TN removal efficiency $((91.6 \pm 1.6) \%)$ was obtained than when using methanol $((85.3 \pm 2.0) \%)$. Rodríguez et al. (2007b) studied six different agro-food wastewaters from cheese production, milk bottling, potato processing, beet sugar processing, tomato processing, and a winery, respectively. Although the measured denitrification rates, in the range of $2.0-4.1 \mathrm{mg} \mathrm{N} /(\mathrm{g} \mathrm{VSS} \cdot \mathrm{h})$, were lower than those obtained for acetate $(4.7 \mathrm{mg} \mathrm{N} /$ (g VSS.h)) and municipal wastewater $(4.3 \mathrm{mg} \mathrm{N} /$ (g VSS.h)), the addition of tomato processing wastewater as the external carbon source raised the denitrification capacity significantly, with $99 \%$ of nitrate nitrogen removed in a full-scale wastewater treatment plant (WWTP). In addition, examples of noticeably higher denitrification rates resulting from the use of industrial effluents can be found in the literature. Cappai et al. (2004) tested wastewaters from the ice-cream industry and a beet-sugar factory and found that the denitrification rates were 6.7 and $5.5 \mathrm{mg} \mathrm{N} /(\mathrm{g}$ VSS$\cdot h)$, respectively. Similar values were obtained with dairy effluent, glycerin and meat processing wastewater. Some other studies, for instance, with glycerol, fusel oil, brewery effluent, and wine distillery effluent revealed values exceeding $13 \mathrm{mg} \mathrm{N} /(\mathrm{g}$ VSS$\cdot h)$ (Monteith et al., 1980; Bernet et al., 1996; Hinojosa et al., 2008; Kampas et al., 2009).

The effect of industrial effluents as external carbon sources in enhancing denitrification in BNR systems has been investigated and reported extensively, but very little is known about their effects as external carbon sources for EBPR. It is well known that in EBPR metabolism, the composition of poly- $\beta$-hydroxyalkanoates (PHAs), including poly- $\beta$ hydroxybutyrate (PHB), poly- $\beta$-hydroxyvalerate (PHV) and poly-3-hydroxy-2-methylvalerate (PH2MV), produced by different types of phosphorus accumulating organisms (PAOs) and denitrifying phosphorus accumulating organisms (DPAOs) during the anaerobic period, varies based on the carbon source. However, PAOs and DPAOs are unable to metabolize these different types of PHA at the same rate in the subsequent anoxic phase (Oehmen et al., 2005a). Therefore, the use of different carbon sources may lead to different properties of phosphorus metabolism and removal. Rodríguez et al. (2007a) evaluated the performance of the use of winery wastewater to enhance the BNR process. A dose of winery wastewater significantly enhanced nitrogen removal (from 58\% to $75 \%$ ). However, the phosphorus removal remained constant. Similar findings were reported by Rodríguez et al. (2007b), who found that the optimum dosage of tomato processing wastewater applied as an external carbon source enhanced nitrate removal, but the COD and phosphorus removal were not significantly affected. However, other studies showed that both nitrogen and phosphorus removals were enhanced by adding external carbon sources. Lee et al. (2003) investigated the feasibility and applicability of anaerobically fermented leachate of food waste (AFLFW) as an external carbon source in a lab-scale 
BNR process treating domestic sewage with a low $\mathrm{C} / \mathrm{N}$ ratio of 4.4. As AFLFW was supplied, not only did the average removal efficiency of $\mathrm{TN}$ increased from $53 \%$ to $74 \%$, but also the total phosphorus (TP) removal efficiency increased from $21 \%$ to $68 \%$. Higher values were reported by Chae et al. (2004) who found that when AFLFW was supplied, the average removal efficiencies of $\mathrm{TN}$ and $\mathrm{TP}$ increased from $53 \%$ to $97 \%$ and from $55 \%$ to $93 \%$, respectively. They attributed the denitrification efficiency and EBPR activity to the concentration of volatile fatty acids (VFAs) in the external carbon source.

In this study, the effects of one kind of food industry effluent, cassava stillage and its anaerobic fermentation liquid, used as external carbon sources, on denitrification and EBPR were investigated. The behavior of intracellular materials including PHA and glycogen affecting the EBPR mechanism was also examined.

\section{Materials and methods}

\subsection{Sequencing batch reactor (SBR) set-up and operation}

We compared the performance, in terms of nitrogen and phosphorus removal, of three bench-scale anaerobic/anoxic/aerobic SBRs, each with a working volume of 3.0 L. The carbon sources for the three SBRs (SA-SBR, CS-SBR and CSF-SBR) were sodium acetate (SA), cassava stillage supernatant (CS) and its anaerobic fermentation liquid (CSF), respectively. The SBRs were completely automated with time controllers regulating all peristaltic pumps, stirrers, air pumps, and phase lengths. Sludge originated from a sewage treatment plant (Quyang Sewage Treatment Plant, Shanghai, China) that employed a BNR process. The three SBRs were operated on three 8-h cycles per day, with each cycle consisting of $10 \mathrm{~min}$ feeding, $90 \mathrm{~min}$ anaerobic, $210 \mathrm{~min}$ anoxic, $40 \mathrm{~min}$ aerobic, followed by $60 \mathrm{~min}$ settling, $10 \mathrm{~min}$ decanting and $70 \mathrm{~min}$ idle periods. During the first 10 min feeding period in each reactor, $1.5 \mathrm{~L}$ of synthetic wastewater was pumped into the reactor, while $50 \mathrm{ml}$ of $\mathrm{KNO}_{3}$ stock solution was pulse-added into the reactors at the beginning of the anoxic period, giving an initial $\mathrm{NO}_{3}^{-}-\mathrm{N}$ concentration of $35 \mathrm{mg} / \mathrm{L}$. During the aerobic phase, the dissolved oxygen (DO) concentration in each SBR was around $3 \mathrm{mg} / \mathrm{L}$, and
$50 \mathrm{ml}$ of sludge was removed daily at the end of the aerobic period, giving a solids retention time (SRT) of about $20 \mathrm{~d}$. Mixed liquor suspended solids (MLSS) concentrations of the three SBRs were around $3000 \mathrm{mg} / \mathrm{L}$, and the hydraulic retention time (HRT) was about $16 \mathrm{~h}$. The SA-SBR and CS-SBR were operated from August to November 2012, while the CSF-SBR was operated from November 2012 to January 2013.

\subsection{Characteristics of the food industry effluents}

The cassava stillage used as a carbon source in this work originated from a full-scale cassava ethanol plant (Jiangsu, China). Before experiments, the stillage was concentrated by settling at $4{ }^{\circ} \mathrm{C}$ for $24 \mathrm{~h}$ and the decanted supernatant (CS) was subsequently used for 5-d anaerobic alkaline fermentation at $\mathrm{pH} 9.0$ and $35^{\circ} \mathrm{C}$. After fermentation, the liquid phase (CSF) was centrifuged at $1000 \mathrm{r} / \mathrm{min}$ for $10 \mathrm{~min}$ and stored at $4{ }^{\circ} \mathrm{C}$ before use. Sample analyses of CS and CSF revealed high $\mathrm{COD}$ concentrations and low total nutrient concentrations (COD/TN ratios of $84 \pm 5.4$ and $53 \pm 4.2$ for CS and CSF, respectively) (Table 1 ). The VFAs produced in CSF contained $35.8 \%$ acetate, $20.9 \%$ propionate, $42.8 \%$ butyrate, and $0.5 \%$ iso-butyric acid. The VFAs were the major COD component with an average VFA/COD ratio of $(73 \pm 0.9) \%$, which was comparable to the obtained $(79 \%-80 \%)$ when using AFLFW as the external carbon source (Lee et al., 2003). The residual carbohydrate in the fermentation liquid contributed to

Table 1 Characteristics of cassava stillage supernant (CS) and its anaerobic fermentation liquid (CSF)

\begin{tabular}{lcc}
\hline \multicolumn{1}{c}{ Constituent } & CS & CSF \\
\hline $\mathrm{pH}$ & $4.57 \pm 0.02$ & $8.10 \pm 0.12$ \\
$\mathrm{COD}(\mathrm{mg} / \mathrm{L})$ & $43720 \pm 320$ & $31580 \pm 260$ \\
$\mathrm{NH}_{3}-\mathrm{N}(\mathrm{mg} / \mathrm{L})$ & $12.0 \pm 1.0$ & $20.0 \pm 1.6$ \\
$\mathrm{TN}(\mathrm{mg} / \mathrm{L})$ & $520 \pm 21$ & $600 \pm 27$ \\
$\mathrm{TP}(\mathrm{mg} / \mathrm{L})$ & $1072 \pm 25$ & $1116 \pm 42$ \\
Soluble carbohydrate $(\mathrm{mg} / \mathrm{L})$ & $13290 \pm 43$ & $2858 \pm 292$ \\
Soluble protein (mg/L) & $3514 \pm 257$ & $983 \pm 57$ \\
Ethanol (mg/L) & $299.8 \pm 13.2$ & $0 \pm 0$ \\
Acetic acid (mg/L) & $249.3 \pm 10.6$ & $8216 \pm 476$ \\
Propionic acid (mg/L) & $0 \pm 0$ & $4801 \pm 33$ \\
Butyric acid (mg/L) & $0 \pm 0$ & $9820 \pm 201$ \\
Iso-butyric acid (mg/L) & $0 \pm 0$ & $126 \pm 6$ \\
Valeric acid (mg/L) & $0 \pm 0$ & $0 \pm 0$ \\
Iso-valeric acid (mg/L) & $0 \pm 0$ & $0 \pm 0$ \\
COD/TN & $84.0 \pm 5.4$ & $53.0 \pm 4.2$ \\
\hline
\end{tabular}

The values are expressed as mean $\pm \mathrm{SD}(n=3)$ 
the remaining COD in the CSF. Compared with the CSF, the main compounds besides acetate contributing to the COD in the CS were carbohydrate and protein. More detailed characteristics of the tested carbon sources are presented in Table 1.

\subsection{Synthetic wastewater}

The synthetic wastewater used in this study contained (per liter): $13.16 \mathrm{mg}$ of $\mathrm{KH}_{2} \mathrm{PO}_{4}(3.0 \mathrm{mg}$ of P), $16.84 \mathrm{mg}$ of $\mathrm{K}_{2} \mathrm{HPO}_{4}(3.0 \mathrm{mg}$ of P), $57.4 \mathrm{mg}$ of $\mathrm{NH}_{4} \mathrm{Cl}(15.0 \mathrm{mg}$ of $\mathrm{N}), 85 \mathrm{mg}$ of $\mathrm{MgSO}_{4} \cdot 7 \mathrm{H}_{2} \mathrm{O}$, $10 \mathrm{mg}$ of $\mathrm{CaCl}_{2}$, and $110 \mathrm{mg}$ of $\mathrm{NaHCO}_{3}$. The three SBRs were supplemented with SA, CS, and CSF, respectively, as the sole carbon source to achieve a feed COD of about $300 \mathrm{mg} / \mathrm{L}$. Additionally, $0.5 \mathrm{ml}$ of mineral salt solution was added per liter of synthetic wastewater. Each liter of mineral salt solution was composed of $5 \mathrm{~g} \mathrm{FeCl}_{3} \cdot 6 \mathrm{H}_{2} \mathrm{O}, 0.15 \mathrm{~g} \mathrm{H}_{3} \mathrm{BO}_{3}, 0.03 \mathrm{~g}$ $\mathrm{CuSO}_{4} \cdot 5 \mathrm{H}_{2} \mathrm{O}, 0.18$ g KI, 0.12 g $\mathrm{MnCl}_{2} \cdot 4 \mathrm{H}_{2} \mathrm{O}$, $0.06 \mathrm{~g} \mathrm{Na}_{2} \mathrm{MoO}_{4} \cdot 2 \mathrm{H}_{2} \mathrm{O}, 0.12 \mathrm{~g} \mathrm{ZnSO}_{4} \cdot 7 \mathrm{H}_{2} \mathrm{O}, 0.15 \mathrm{~g}$ $\mathrm{CoCl}_{2} \cdot 6 \mathrm{H} 2 \mathrm{O}$, and $10 \mathrm{~g}$ ethylene diamine tetraacetic acid (EDTA). The wastewater was fed into the three SBRs at the beginning of each cycle, giving the feed of each SBR about $300 \mathrm{mg} / \mathrm{L}$ COD, $6 \mathrm{mg} / \mathrm{L}$ soluble ortho-phosphorus (SOP), and $15 \mathrm{mg} / \mathrm{L} \mathrm{NH}_{4}{ }^{+}-\mathrm{N}$.

\subsection{Batch experiments}

\subsubsection{Conventional NURs}

Fresh activated sludge from the three steadystate SBRs at the end of the decanting period and the three carbon sources were mixed, respectively, to obtain $1.5 \mathrm{~L}$ of mixed liquor with volatile suspended solids (MLVSS) concentration of about $2000 \mathrm{mg} / \mathrm{L}$. Measurements were recorded for $6 \mathrm{~h}$ after injecting $\mathrm{KNO}_{3}$ stock solution to raise the initial $\mathrm{NO}_{3}{ }^{-}-\mathrm{N}$ concentration to $30 \mathrm{mg} / \mathrm{L}$. Samples were withdrawn at a frequency of 5-30 min and filtered through Millipore filter units $(0.45 \mu \mathrm{m}$ pore size) for analyses of COD, $\mathrm{NO}_{2}{ }^{-}-\mathrm{N}$, and $\mathrm{NO}_{3}{ }^{-}-\mathrm{N}$.

\subsubsection{Anaerobic-anoxic/aerobic tests}

Mixed liquor (1.5 L) containing active biomass from the three steady-state SBRs during the aerobic period was incubated in the SBRs and maintained in anaerobic conditions in the presence of one of the three carbon sources to reach a COD of $300 \mathrm{mg} / \mathrm{L}$. The sludge was homogenized in the anaerobic phase to promote phosphate release and COD uptake for $4 \mathrm{~h}$.
Subsequently, mixed liquor in each batch reactor was divided into two sets to perform the anoxic/aerobic phosphate uptake experiments: one set was exposed to anoxic conditions for $3 \mathrm{~h}$ where $\mathrm{KNO}_{3}$ stock solution was added at the beginning of anoxic to produce an $\mathrm{NO}_{3}{ }^{-}-\mathrm{N}$ concentration of $30 \mathrm{mg} / \mathrm{L}$; the other set was exposed to aerobic conditions for $3 \mathrm{~h}$ where air was injected into the mixture to maintain the DO concentrations at around $3 \mathrm{mg} / \mathrm{L}$. Samples were withdrawn at a frequency of 20-30 min and filtered through Millipore filter units $(0.45 \mu \mathrm{m}$ pore size) for analyses of $\mathrm{COD}$ and $\mathrm{PO}_{4}{ }^{3-}-\mathrm{P}$. The phosphate uptake rates (PURs) under anoxic and aerobic conditions were estimated from the linear regression of phosphate concentrations. The ratio of the anoxic PUR to the aerobic PUR was used as an index (denoted $K$ ) reflecting the fraction of DPAOs (Wachtmeister et al., 1997).

\subsection{Analytical methods}

The liquid samples from the three SBRs were immediately filtered through Millipore filter units $(0.45 \mu \mathrm{m}$ pore size $)$ for analyses of $\mathrm{COD}, \mathrm{NH}_{4}{ }^{+} \mathrm{N}$, $\mathrm{NO}_{2}^{-}-\mathrm{N}, \mathrm{NO}_{3}{ }^{-}-\mathrm{N}, \mathrm{TN}, \mathrm{PO}_{4}{ }^{3-}-\mathrm{P}$, and TP. COD, TN, $\mathrm{PO}_{4}{ }^{3-}-\mathrm{P}, \mathrm{TP}, \mathrm{MLSS}$, and MLVSS were measured according to standard methods (APHA, 1998). $\mathrm{NH}_{4}{ }^{+}-\mathrm{N}, \mathrm{NO}_{2}{ }^{-}-\mathrm{N}$, and $\mathrm{NO}_{3}{ }^{-}-\mathrm{N}$ were analyzed by ion chromatography using two conductivity detectors and two sets of columns (Dionex ICS-3000). The soluble carbohydrate concentration was measured by the phenol sulfuric acid method, with glucose as standard (Dubois et al., 1956). Soluble protein was determined by the Lowry-Folin method with bovine serum albumin as standard (Lowry et al., 1951). Samples for the analyses of ethanol and VFAs (acetic, propionic, butyric, iso-butyric, valeric, iso-valeric acids) were diluted with a $3 \%(0.03 \mathrm{~g} / \mathrm{ml}) \mathrm{H}_{3} \mathrm{PO}_{4}$ solution (sample/ acid $1: 1, \mathrm{v} / \mathrm{v}$ ) and were analyzed by gas chromatography (GC; Agilent, $6890 \mathrm{~N}$ ) using a flame ionization detector (FID) and analytical column CPWAX52CB $(30 \mathrm{~m} \times 0.25 \mathrm{~mm} \times 0.25 \mu \mathrm{m})$. The temperatures of the injector and FID were 200 and $220{ }^{\circ} \mathrm{C}$, respectively. Nitrogen gas was used as the carrier gas with a flow rate of $25 \mathrm{ml} / \mathrm{min}$. The temperature of GC-oven was programmed to begin at $110^{\circ} \mathrm{C}$ and remain there for $2 \mathrm{~min}$, then increase at a rate of $10{ }^{\circ} \mathrm{C} / \mathrm{min}$ to $220^{\circ} \mathrm{C}$, and hold at $220^{\circ} \mathrm{C}$ for an additional $2 \mathrm{~min}$. The sample injection volume was $1.0 \mu$ l.

The analyses of PHB, PHV, and PH2MV were conducted according to the method described by 
Oehmen et al. (2005b). Lyophilized sludge samples were digested, methylated, and extracted with chloroform. The extracted methyl esters were then identified using an HP $4890 \mathrm{GC}$ equipped with an FID detector and a $30 \mathrm{~m} \times 0.53 \mathrm{~mm} \times 0.88 \mu \mathrm{m} \mathrm{HP}-5$ column. Helium was the carrier gas with a flow rate of $30 \mathrm{ml} / \mathrm{min}$. The GC-oven temperature was programmed to begin at $120{ }^{\circ} \mathrm{C}$ and remain there for $2 \mathrm{~min}$, then increase at a rate of $8{ }^{\circ} \mathrm{C} / \mathrm{min}$ to $200{ }^{\circ} \mathrm{C}$ and hold at $200^{\circ} \mathrm{C}$ for an additional $2 \mathrm{~min}$, and lastly increase at a rate of $15^{\circ} \mathrm{C} / \mathrm{min}$ to $270{ }^{\circ} \mathrm{C}$ and hold at $270{ }^{\circ} \mathrm{C}$ for an additional $5 \mathrm{~min}$. The standards of PHB/PHV (88\%/12\%) and poly-2-hydroxycaproic acid were purchased from the Sigma-Aldrich Chemical Company (USA) and used for the establishment of the calibration curve. Note that no standard sample was available for the direct measurement of PH2MV. As poly-2-hydroxycaproic acid and $\mathrm{PH} 2 \mathrm{MV}$ are isomers, poly-2-hydroxycaproic acid was used for the standard curve of PH2MV. The total PHA in the samples was calculated as the sum of the measured PHB, PHV, and PH2MV. Glycogen was determined using the method described by Fang et al. (2002).

\section{Results}

\subsection{Comparison of COD transformations with different carbon sources}

Cyclic studies were performed in the three SBRs after stable nutrient and phosphorus conversions were achieved. Fig. 1 shows the COD concentration profiles in the three SBRs. During the anaerobic stage, carbon sources were rapidly consumed in both the SA-SBR and CSF-SBR, even if a little slowly in CSF-SBR, with the COD concentrations at 64 and $82 \mathrm{mg} / \mathrm{L}$ at the end of the anaerobic period in the SA-SBR and CSF-SBR, respectively. In the CS-SBR, the COD concentration was higher at $189 \mathrm{mg} / \mathrm{L}$, due to the high amount of compounds of large molecular size, such as carbohydrate and protein, in CS. Small molecules like VFAs, can be easily used by the storage of PHA and the release of phosphorus in the anaerobic period. In the subsequent anoxic period, the COD concentration decreased continuously in the CS-SBR. The COD concentrations at the end of anoxic period were 29, 42 , and $82 \mathrm{mg} / \mathrm{L}$ in the SA-SBR, CSF-SBR, and
CS-SBR, respectively. The higher effluent COD concentration in the CS-SBR indicated that pre-treatment of $\mathrm{CS}$, such as anaerobic alkaline fermentation, was necessary to facilitate the biodegradation of large molecules.

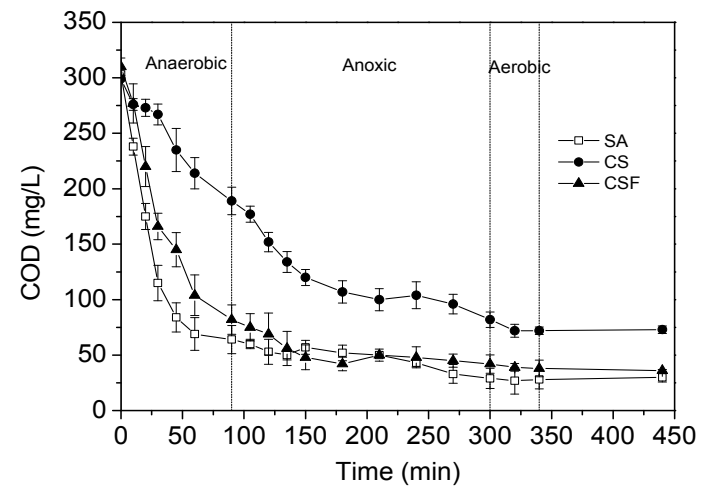

Fig. 1 Variation in COD in three SBRs fed with different carbon sources

The values are expressed as mean $\pm \mathrm{SD}(n=3)$

\subsection{Comparison of nitrogen transformations with different carbon sources}

The variations in $\mathrm{NH}_{4}{ }^{+}-\mathrm{N}, \mathrm{NO}_{2}^{-}-\mathrm{N}$, and $\mathrm{NO}_{3}{ }^{-}-\mathrm{N}$ in the three SBRs are shown in Fig. 2. Ammonium was rapidly oxidized and decreased in the aerobic stages, accompanied by increases in $\mathrm{NO}_{2}^{-}-\mathrm{N}$ and $\mathrm{NO}_{3}{ }^{-}-\mathrm{N}$. The three SBRs all achieved high ammonia oxidation rates in the aerobic stage, and the ammonia was eventually removed. In the anoxic period, once $\mathrm{KNO}_{3}$ solution was added, the denitrification process started. The $\mathrm{NO}_{3}{ }^{-}-\mathrm{N}$ concentration became depleted and then remained constant in the SA-SBR after $60 \mathrm{~min}$, while in the CS-SBR and CSF-SBR it continued to go down. During the anoxic stage, the specific denitrification rates in the CS-SBR and CSF-SBR were 2.71 and $3.19 \mathrm{mg} \mathrm{NO}_{x}{ }^{-}-\mathrm{N} /$ (g MLVSS $h$ ), respectively, while the SA-SBR demonstrated a higher rate of $4.45 \mathrm{mg} \mathrm{NO}_{x}{ }^{-}-\mathrm{N} /$ ( $g$ MLVSS $\cdot h$ ). At the end of the anoxic stage, the $\mathrm{NO}_{x}^{-}$-N concentrations in the CSF-SBR, CS-SBR and SA-SBR were (6.63 \pm 0.71$),(12.83 \pm 0.77)$, and $(15.50 \pm$ $0.52) \mathrm{mg} / \mathrm{L}$, respectively, resulting in a higher $\mathrm{TN}$ removal efficiency in the CSF-SBR $((73.1 \pm 1.3) \%)$ and CS-SBR $((61.6 \pm 0.9) \%)$ than in the SA-SBR $((55.2 \pm 2.0) \%)$ at the end of the aerobic period. Note that significant $\mathrm{NO}_{2}{ }^{-}-\mathrm{N}$ accumulation occurred during denitrification in the three reactors. This can be 
attributed to the slower rate of reduction of nitrite compared with when there is limited availability of biodegradable organic carbon (Oh and Silverstein, 1999). The timing of the peak $\mathrm{NO}_{2}^{-}-\mathrm{N}$ concentration in the SA-SBR $(2.25 \mathrm{~h})$ was earlier than that of the CS-SBR $(2.5 \mathrm{~h})$ and CSF-SBR $(3 \mathrm{~h})$ (Fig. 2c). However, the peak $\mathrm{NO}_{2}{ }^{-}-\mathrm{N}$ concentrations in the CSF-SBR and CS-SBR were $(6.26 \pm 0.31)$ and $(16.06 \pm$ $0.75) \mathrm{mg} / \mathrm{L}$, respectively, much lower than that in the SA-SBR $((24.01 \pm 1.02) \mathrm{mg} / \mathrm{L})$ during the anoxic stage. These observations suggest that $\mathrm{NO}_{2}^{-}-\mathrm{N}$ accumulation is linked to the carbon source and denitrification rate (Zhou et al., 2008; Wang et al., 2011).

\subsection{Comparison of $\mathrm{PO}_{4}{ }^{3-}-\mathrm{P}, \mathrm{PHA}$, and glycogen transformations with different carbon sources}

3.3.1 Effects of carbon sources on the transformation of $\mathrm{PO}_{4}{ }^{3-}-\mathrm{P}$

As mentioned above, the carbon sources were rapidly consumed during the anaerobic stage, and this process was accompanied by the release of phosphorus, the formation of PHA, and the degradation of glycogen. The variation in $\mathrm{PO}_{4}{ }^{3-}-\mathrm{P}$ during cyclic studies in the three SBRs is illustrated in Fig. 3. Significant anaerobic phosphate release and aerobic phosphate uptake occurred in the three SBRs. Note that in the anoxic stage, significant anoxic $\mathrm{P}$ uptake occurred concurrently with denitrification in both the CS-SBR and CSF-SBR, but not in the SA-SBR. This indicates that EBPR may occur in the CS-SBR and CSF-SBR.

The specific anaerobic phosphorus release in the SA-SBR ((4.45 \pm 0.28$) \mathrm{mg} \mathrm{PO}_{4}{ }^{3-}-\mathrm{P} / \mathrm{g}$ MLVSS) was higher than that in the CS-SBR $((2.13 \pm 0.15) \mathrm{mg}$

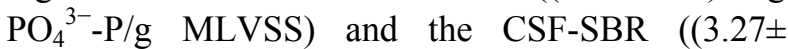
$0.26) \mathrm{mg} \mathrm{PO}_{4}{ }^{3-}-\mathrm{P} / \mathrm{g}$ MLVSS), as shown in Table 2. However, the largest difference between $\mathrm{P}$ uptake and release occurred in the CSF-SBR $((2.46 \pm 0.17) \mathrm{mg}$ $\mathrm{PO}_{4}{ }^{3-}-\mathrm{P} / \mathrm{g}$ MLVSS), followed by the SA-SBR $\left((2.36 \pm 0.18) \mathrm{mg} \mathrm{PO}_{4}{ }^{3-}-\mathrm{P} / \mathrm{g}\right.$ MLVSS $)$ and the CS-SBR $\left((1.80 \pm 0.17) \mathrm{mg} \mathrm{PO}{ }_{4}^{3-}-\mathrm{P} / \mathrm{g}\right.$ MLVSS). Better phosphorus removal efficiencies were achieved in the CSF-SBR $((67.1 \pm 2.5) \%)$ and the CS-SBR $((78.6 \pm$ $3.7) \%)$ than in the SA-SBR $((56.5 \pm 3.1) \%)$. Better phosphorus removal was also obtained using VFAs derived from the fermenter as the carbon source than by dosing an equivalent amount of acetic acid (Thomas et al., 2003).
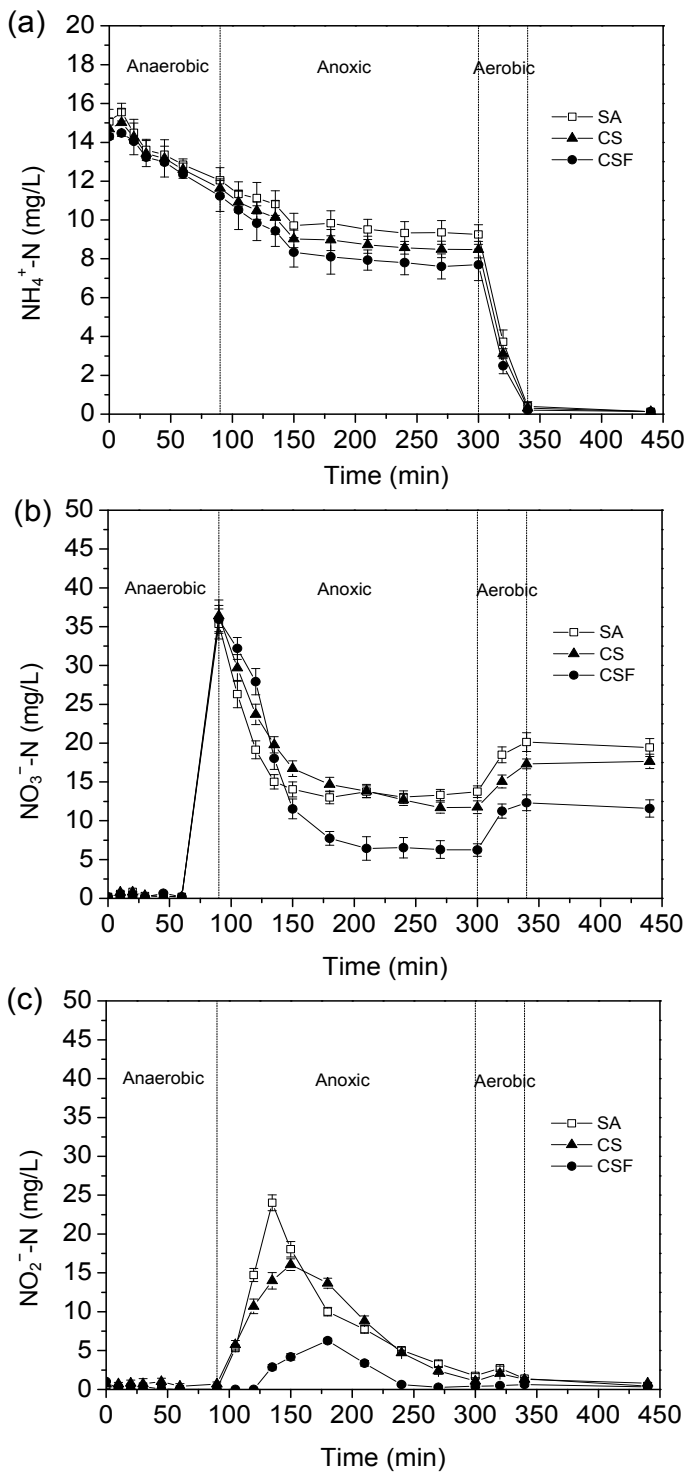

Fig. 2 Variations in $\mathrm{NH}_{4}{ }^{+}-\mathrm{N}(\mathrm{a}), \mathrm{NO}_{3}{ }^{-} \mathrm{N}(\mathrm{b})$, and $\mathrm{NO}_{2}{ }^{-} \mathrm{N}(\mathrm{c})$ in three SBRs fed with different carbon sources The values are expressed as mean $\pm \mathrm{SD}(n=3)$

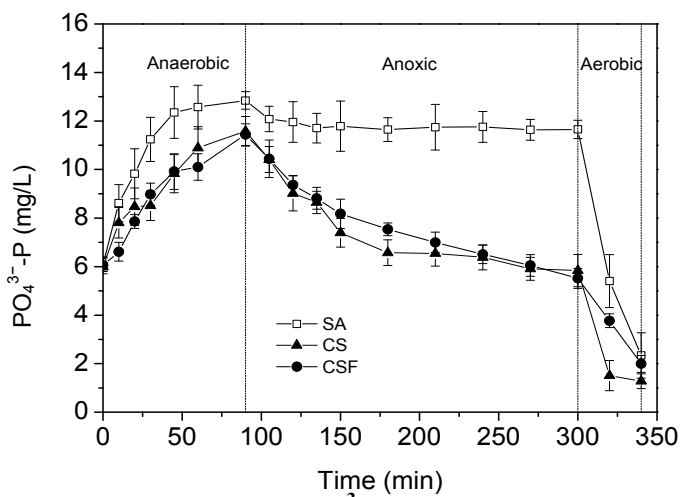

Fig. 3 Variation in $\mathrm{PO}_{4}{ }^{3-}-\mathrm{P}$ in three $\mathrm{SBRs}$ fed with different carbon sources

The values are expressed as mean $\pm \mathrm{SD}(n=3)$ 
Table 2 Transformation of $\mathrm{PO}_{4}{ }^{3-}-\mathrm{P}, \mathrm{PHA}$, and glycogen in three SBRs with different carbon sources

\begin{tabular}{|c|c|c|c|}
\hline Parameter & SA & $\mathrm{CS}$ & $\mathrm{CSF}$ \\
\hline Initial $\mathrm{P}$ concentration $(\mathrm{mg} / \mathrm{L})$ & $6.06 \pm 0.37$ & $5.99 \pm 0.40$ & $6.05 \pm 0.42$ \\
\hline Specific anaerobic $\mathrm{P}$ release $\left(\mathrm{mg} \mathrm{PO}_{4}{ }^{3-}-\mathrm{P} / \mathrm{g}\right.$ MLVSS $)$ & $4.45 \pm 0.28$ & $2.13 \pm 0.15$ & $3.27 \pm 0.26$ \\
\hline Anoxic $\mathrm{P}$ uptake ( $\mathrm{mg} \mathrm{PO}_{4}{ }^{3-}-\mathrm{P} / \mathrm{g}$ MLVSS) & $0.47 \pm 0.10$ & $2.19 \pm 0.23$ & $3.59 \pm 0.29$ \\
\hline Aerobic $\mathrm{P}$ uptake (mg $\mathrm{PO}_{4}{ }^{3-}-\mathrm{P} / \mathrm{g}$ MLVSS) & $6.34 \pm 0.37$ & $1.74 \pm 0.14$ & $2.14 \pm 0.20$ \\
\hline Difference between $\mathrm{P}$ uptake and release $\left(\mathrm{mg} \mathrm{PO}_{4}{ }^{3-}-\mathrm{P} / \mathrm{g}\right.$ MLVSS) & $2.36 \pm 0.18$ & $1.80 \pm 0.17$ & $2.46 \pm 0.17$ \\
\hline Aerobic end $\mathrm{P}$ concentration $(\mathrm{mg} / \mathrm{L})$ & $2.64 \pm 0.25$ & $1.28 \pm 0.20$ & $1.99 \pm 0.26$ \\
\hline P removal efficiency $(\%)$ & $56.5 \pm 3.1$ & $78.6 \pm 3.7$ & $67.1 \pm 2.5$ \\
\hline PHA synthesis (mmol C/g MLVSS) & $3.27 \pm 0.14$ & $2.62 \pm 0.11$ & $2.07 \pm 0.10$ \\
\hline Glycogen degradation (mmol C/g MLVSS) & $2.14 \pm 0.11$ & $1.23 \pm 0.05$ & $0.98 \pm 0.06$ \\
\hline PHA degradation (mmol C/g MLVSS) & $2.78 \pm 0.09$ & $2.45 \pm 0.06$ & $1.57 \pm 0.06$ \\
\hline Glycogen synthesis (mmol C/g MLVSS) & $2.29 \pm 0.06$ & $1.31 \pm 0.04$ & $1.18 \pm 0.06$ \\
\hline
\end{tabular}

The values are expressed as mean $\pm \mathrm{SD}(n=3)$

3.3.2 Effects of carbon sources on the transformation of PHA and glycogen

The structure of PHA formed in cells depends on the characteristics of substrates and microorganisms in the system (Chae et al., 2004; Li et al., 2008; Pijuan et al., 2009). The transformation of PHA in the three SBRs is shown in Fig. 4. When SA was used as a substrate, PHB was the major compound, with the average compositions of $\mathrm{PHB}, \mathrm{PHV}$, and $\mathrm{PH} 2 \mathrm{MV}$ being $97.6 \%, 2.0 \%$, and $0.4 \%$, respectively. When CS and CSF were used as the substrates, a decrease in PHB and an increase in PHV and PH2MV of PHA occurred, with the average compositions of PHB, PHV, and PH2MV being $78.6 \%, 18.0 \%$, and $3.4 \%$, respectively, in CS-SBR and $49.3 \%, 41.1 \%$, and $9.6 \%$, respectively, in CSF-SBR. These findings correspond well with the results of other studies showing that the ratio of PHB synthesis/PHA synthesis decreases when the carbon source has a higher ratio of propionate/acetate (Lemos et al., 2003; Wang et al., 2011). In addition, negligible or very little amounts of PH2MV were anaerobically synthesized in the three SBRs. These findings correspond with those of other studies (Pijuan et al., 2009; Wang et al., 2011).

The reducing power necessary for anaerobic PHA accumulation is primarily derived from the degradation of stored glycogen (Fig. 4c). The amount of anaerobic glycogen degradation decreased when the carbon source was changed from SA $((2.14 \pm$ $0.11) \mathrm{mmol} \mathrm{C/g}$ MLVSS) to CS ((1.23 \pm 0.05$) \mathrm{mmol} \mathrm{C/}$ g MLVSS) or CSF $((0.98 \pm 0.06) \mathrm{mmol}$ C/g MLVSS $)$, which was responsible for a trend similar to the amount of PHA synthesis in each reactor (Fig. 5, Table 2). On the other hand, glycogen transformation showed a trend similar to PHA degradation. The
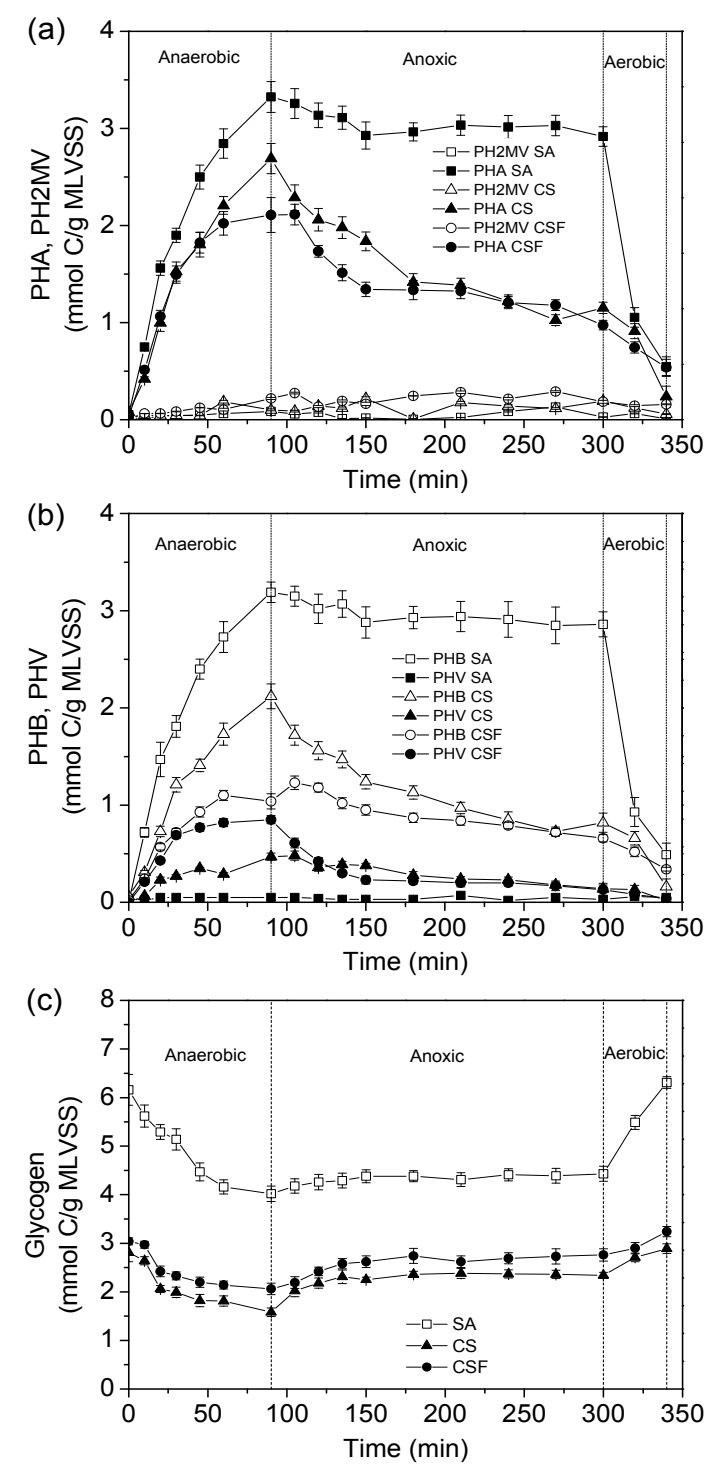

Fig. 4 Variation in PHA, PH2MV (a), PHB, PHV (b), and glycogen (c) in three SBRs fed with different carbon sources

The values are expressed as mean $\pm \mathrm{SD}(n=3)$ 
glycogen replenishments in the CS-SBR ((1.31

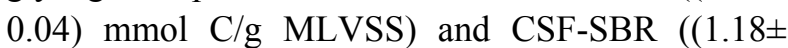
$0.06) \mathrm{mmol} \mathrm{C} / \mathrm{g}$ MLVSS) were lower than that in the SA-SBR $((2.29 \pm 0.06) \mathrm{mmol} \mathrm{C} / \mathrm{g}$ MLVSS). This suggests that more PHA would be saved for taking up more phosphate, although the PHA accumulation was lower in the CS-SBR and the CSF-SBR. Thus, higher TP removal efficiencies were observed in the CSSBR and CSF-SBR than in the SA-SBR.
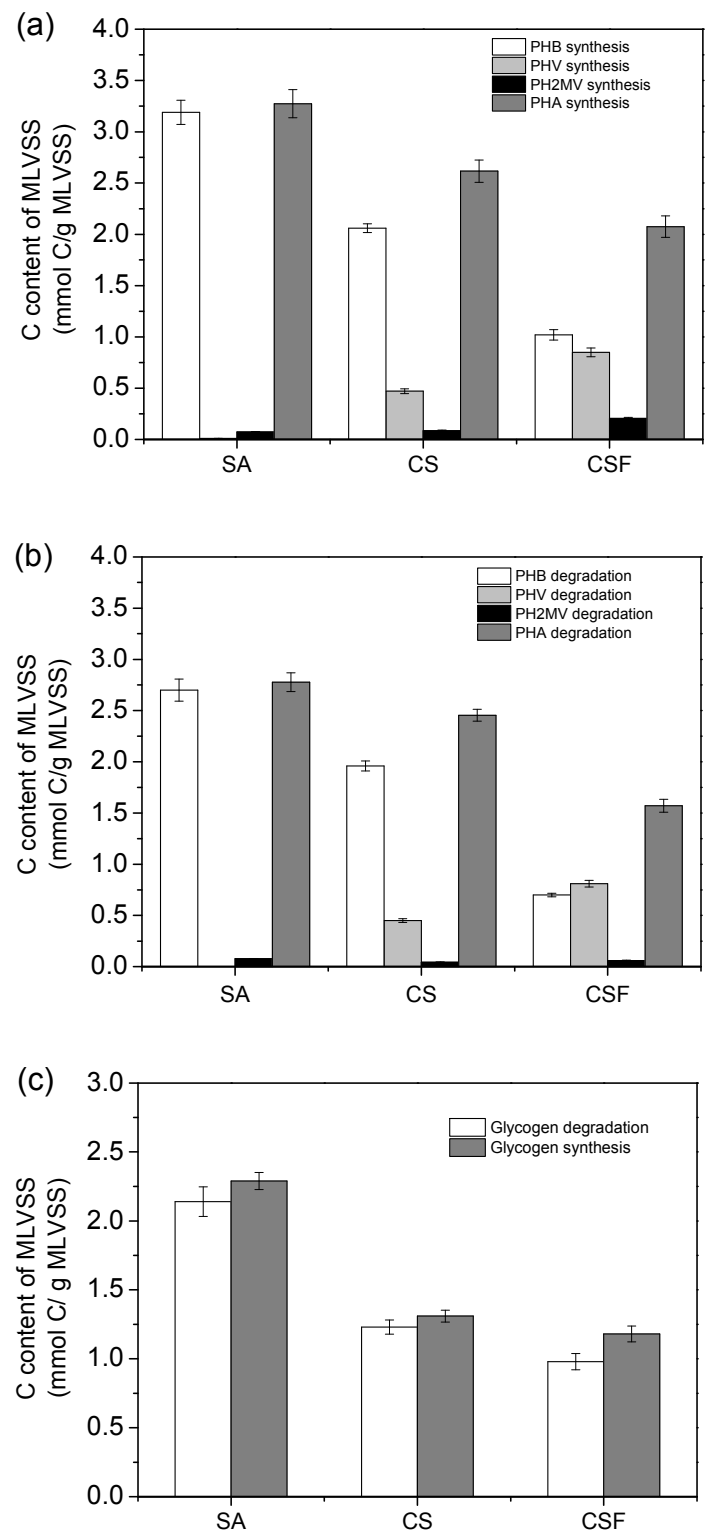

Fig. 5 Effects of carbon sources on PHA synthesis (a), PHA degradation (b), and glycogen synthesis/ degradation (c) in three SBRs

The values are expressed as mean $\pm \mathrm{SD}(n=3)$

\subsection{Batch tests}

\subsubsection{Conventional NURs}

The specific conventional NUR values measured with SA, CS, and CSF are listed in Table 3, and the experimental results are illustrated in Fig. 6. In the experiments with the CS, the NURs associated with use of the readily biodegradable COD (RBCOD) (NUR1) and the slowly biodegradable fraction (NUR2) varied in the ranges of 5.49-5.99 and 0.80-1.06 g N/(kg MLVSS·h), respectively. These results suggested that the RBCOD was used first, but many of the other CODs (e.g. particulate COD or macromolecular compounds) were used subsequently and more slowly. Moreover, the explicit double rates observed in this study resulted from the content of various COD fractions in $\mathrm{CS}$, revealing different rates of biodegradability, similar to other industry wastewaters used as external carbon sources (Rodríguez et al., 2007a; 2007b; Swinarski et al., 2009a). In the case of CSF, a single NUR value was observed. This could be explained by taking into account that the fermentation substrates were the most abundant COD fraction in the CSF studied. The NUR of CSF remained in the range of 6.63-6.81 g N/ (kg MLVSS·h), which was slightly higher than the range associated with the use of the RBCOD in the CS (5.49-5.99 g N/(kg MLVSS·h)). The measured NURs of the CS and CSF were similar to or higher than those of other industry wastewaters as external carbon sources (Table 3), indicating that CS and CSF could be economically and environmentally sound external COD sources for the denitrification process.

The biodegradable organic compounds were less effective during the experiments with the industrial wastewater, which was reflected by much higher $\Delta \mathrm{COD} / \Delta \mathrm{N}$ ratios $(\Delta \mathrm{COD}$ is the amount of removed $\mathrm{COD}$ and $\Delta \mathrm{N}$ is the amount of nitrogen removed) with CS (11.11-11.56 g COD/g N) and CSF (10.07-10.38 g $\mathrm{COD} / \mathrm{g} \mathrm{N})$ than with SA (9.20-9.84 g COD/g N). This can be explained as follows: it is most likely that the $0.45 \mu \mathrm{m}$ filters used to determine soluble COD (SCOD), allowed colloidal matter to be included in the SCOD determination. This colloidal matter may be removed instantaneously by sorption and may not be associated with the SCOD removal determined during denitrification (Swinarski et al., 2009a). 
Table 3 Comparison of NURs when using different carbon sources

\begin{tabular}{|c|c|c|c|c|}
\hline Carbon source & $\begin{array}{c}\text { Process temperature } \\
\left({ }^{\circ} \mathrm{C}\right)\end{array}$ & $\begin{array}{c}\Delta \mathrm{COD} / \Delta \mathrm{N} \text { ratio } \\
(\mathrm{g} \mathrm{COD} / \mathrm{g} \mathrm{N})\end{array}$ & $\begin{array}{c}\text { NUR } \\
(\mathrm{g} \mathrm{N} /(\mathrm{kg} \text { MLVSS } \cdot \mathrm{h}))\end{array}$ & Literature \\
\hline AFLFW & 20 & & 8.2 & Lee et al., 2003 \\
\hline $\begin{array}{l}\text { Ice cream production industry } \\
\text { wastewater }\end{array}$ & 20 & & 3.28 & Cappai et al., 2004 \\
\hline Beet-sugar industry wastewater & 20 & & 2.72 & Cappai et al., 2004 \\
\hline Hydrolized molasses & & & $2.9-3.6$ & Quan et al., 2005 \\
\hline Dairy effluent & & & $3.4-8.0$ & Sage et al., 2006 \\
\hline $\begin{array}{l}\text { Beet-sugar processing } \\
\text { wastewater }\end{array}$ & 20 & & $\begin{array}{l}2.5(\text { NUR 1) } \\
1.7(\text { NUR 2) }\end{array}$ & Rodríguez et al., 2007b \\
\hline Potato processing wastewater & 20 & & $\begin{array}{l}4.1 \text { (NUR 1) } \\
1.7 \text { (NUR 2) }\end{array}$ & $\begin{array}{l}\text { Rodríguez et al., 2007a; } \\
\quad 2007 \mathrm{~b}\end{array}$ \\
\hline Milk bottling wastewater & 20 & & $\begin{array}{l}3.8 \text { (NUR 1) } \\
1.3 \text { (NUR 2) }\end{array}$ & $\begin{array}{l}\text { Rodríguez et al., 2007a; } \\
\quad 2007 \mathrm{~b}\end{array}$ \\
\hline Cheese industry wastewater & 20 & & $\begin{array}{l}2.8 \text { (NUR 1) } \\
1.1 \text { (NUR 2) }\end{array}$ & $\begin{array}{l}\text { Rodríguez et al., 2007a; } \\
\quad 2007 \mathrm{~b}\end{array}$ \\
\hline Tomato processing wastewater & 20 & & $\begin{array}{l}2.7 \text { (NUR 1) } \\
1.9 \text { (NUR 2) }\end{array}$ & $\begin{array}{l}\text { Rodríguez et al., } 2007 \mathrm{a} ; \\
2007 \mathrm{~b}\end{array}$ \\
\hline Winery wastewater & 20 & & $\begin{array}{l}2.0(\text { NUR 1) } \\
1.8 \text { (NUR 2) }\end{array}$ & $\begin{array}{l}\text { Rodríguez et al., 2007a; } \\
\quad 2007 \mathrm{~b}\end{array}$ \\
\hline Brewery effluent & 20 & & 15.6 & Kampas et al., 2009 \\
\hline Distillery wastewater & $23.1-24.0$ & $11.1-12.7$ & $4.8-5.1$ & Swinarski et al., 2009b \\
\hline Bewery wastewater & $19.7-22.7$ & $6.5-20.8$ & $2.4-6.0$ & Swinarski et al., 2009b \\
\hline Fish-picking wastewater & $21.4-23.0$ & $11.7-13.1$ & $4.0-6.0$ & Swinarski et al., 2009b \\
\hline SA & $18.9-23.1$ & $9.20-9.84$ & $16.69-13.62$ & This study \\
\hline CS & $19.6-21.9$ & $11.11-11.56$ & $\begin{array}{l}5.49-5.99 \text { (NUR 1) } \\
0.80-1.06 \text { (NUR 2) }\end{array}$ & This study \\
\hline CSF & $12.8-13.1$ & $10.07-10.38$ & $6.63-6.81$ & This study \\
\hline
\end{tabular}

AFLFW: anaerobically fermented leachate of food waste; NUR1: the NURs associated with use of the readily biodegradable COD (RBCOD); NUR2: the NURs associated with use of the slowly biodegradable fraction

\subsubsection{Anaerobic-anoxic/aerobic tests}

Cyclic studies demonstrated that the SBRs fed with CS and CSF as the sole carbon source displayed EBPR. Therefore, anaerobic-anoxic/aerobic tests were carried out to quantify the PAO and DPAO activity in the systems. Anoxic P uptake indeed occurred in both the CS-SBR and CSF-SBR, but not in the SA-SBR (Fig. 7). Thomas et al. (2003) proposed that glycogen accumulating organisms (GAOs) have a competitive advantage by using acetate and PAOs have a competitive advantage by using propionate, butyrate, or some other SCOD compounds in the fermenter effluent. This may be why there was no EBPR in the SA-SBR, in which acetate facilitated the GAO growth. However, further research is needed to clarify this issue. It is important to observe that $\mathrm{P}$ release in anaerobic period and $\mathrm{P}$ uptake in the aerobic period increased during the experimental period (Table 4), similar to the results of Monclús et al. (2010). Since the energy production efficiency of
DPAOs growing with nitrate instead of oxygen is about $40 \%$ lower than that of PAOs (Kuba et al., 1996a), the anoxic PUR value of DPAOs is generally lower than the aerobic PUR value of PAOs (Table 4). This means that the $\mathrm{P}$ uptake activity by PAOs was higher than by that DPAOs (Peng et al., 2006; Oehmen et al., 2007). As the lower energy production efficiency of DPAOs growing under anoxic conditions results in a $20 \%-30 \%$ lower cell yield (Kuba et al., 1996a), it is expected that PAOs would outcompete DPAOs and that the DPAO/PAO ratio would decrease with time (Monclús et al., 2010). On Day 86, 62.6\% of the population in PAOs was in the form of DPAOs in the CS-SBR, while this proportion decreased to $49.1 \%$ on Day 100 . Nevertheless, simultaneous nitrogen and phosphorus removal by DPAOs requires less demand for oxygen and carbon sources, which leads to reduced plant operational costs (Kuba et al., 1996b). Therefore, the use of DPAOs for BNR processes is very economical and attractive. 

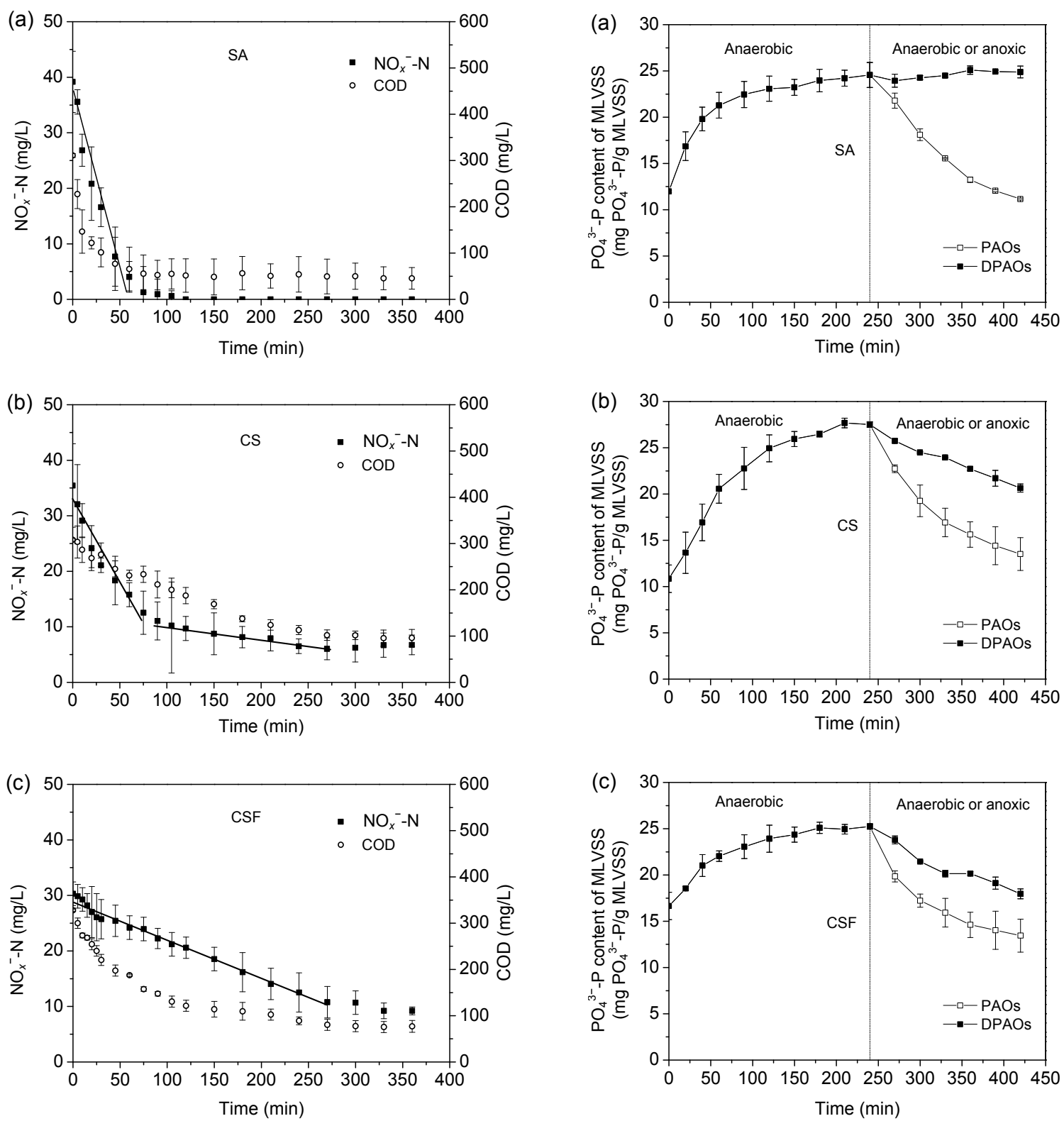

Fig. $6 \mathrm{NO}_{x}^{-}-\mathrm{N}$ and COD consumption in NUR measurements with SA (a), CS (b), or CSF (c) as the sole carbon source The values are expressed as mean $\pm \mathrm{SD}(n=3)$

Fig. 7 Specific $P$ release and uptake when using SA (a), CS (b), or CSF (c) as the sole carbon source

The values are expressed as mean $\pm \mathrm{SD}(n=3)$

Table 4 Comparison between anoxic and aerobic phosphorus uptakes when using different carbon sources

\begin{tabular}{clcccc}
\hline $\begin{array}{c}\text { Carbon } \\
\text { source }\end{array}$ & Time & $\begin{array}{c}\mathrm{P}_{\text {rea }} \text { rate } \\
\left(\mathrm{mg} \mathrm{PO}_{4}{ }^{3-}-\mathrm{P} /(\mathrm{g} \text { MLVSS} \cdot \mathrm{h})\right)\end{array}$ & $\begin{array}{c}\text { Anoxic } \mathrm{P}_{\text {upt }} \text { rate } \\
\left(\mathrm{mg} \mathrm{PO}_{4}{ }^{3-}-\mathrm{P} /(\mathrm{g} \text { MLVSS} \cdot \mathrm{h})\right)\end{array}$ & $\begin{array}{c}\text { Aerobic } \mathrm{P}_{\text {upt }} \text { rate } \\
\left(\mathrm{mg} \mathrm{PO}_{4}{ }^{3-}-\mathrm{P} /(\mathrm{g} \text { MLVSS} \cdot \mathrm{h})\right)\end{array}$ & $\begin{array}{c}\text { DPAO } \\
(\%)\end{array}$ \\
\hline $\mathrm{SA}$ & Day 86 & 2.93 & 0 & 4.13 & 0 \\
& Day 100 & 3.36 & 0 & 4.81 & 0 \\
$\mathrm{CS}$ & Day 86 & 3.61 & 2.26 & 3.61 & 62.6 \\
& Day 100 & 4.73 & 2.32 & 4.72 & 49.1 \\
$\mathrm{CSF}$ & Day 65 & 2.15 & 2.43 & 3.93 & 61.8 \\
& Day 79 & 2.51 & 2.29 & 4.26 & 53.8 \\
\hline
\end{tabular}

$\mathrm{P}_{\text {rea }}: \mathrm{P}$ release in anaerobic period; $\mathrm{P}_{\text {upt }}: \mathrm{P}$ uptake in the anoxic or aerobic period 


\subsection{SBR performance}

Table 5 depicts the performance of the three SBRs at steady-state conditions in terms of removal efficiencies of $\mathrm{COD}, \mathrm{NH}_{4}{ }^{+}-\mathrm{N}, \mathrm{TN}$, and TP. It is evident that the effluent COD concentrations in the CS-SBR were relatively high compared with those in the SA-SBR and CSF-SBR. This suggests that the addition of CS as carbon source may have led to the increase in effluent COD concentration. Lee et al. (2003) stated that compounds with a molecular size of more than $30 \mathrm{kDa}$ are not easily used by microorganisms. $\mathrm{NH}_{4}{ }^{+}-\mathrm{N}$ removal was not adversely affected in the case of the addition of CS and CSF as the sole carbon source in comparison with SA. The TN removal efficiency was higher than $60 \%$ in all three SBRs, and highest in the CSF-SBR ((73.2 \pm 2.6$) \%)$. In addition, comparatively higher TP removal efficiency was observed in the CS-SBR $((74.1 \pm 10.8) \%)$ and

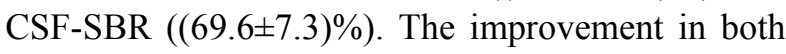
nitrogen and phosphorus removal and the advantage of reducing the amount of cassava stillage to be treated in-situ, suggest that the use of cassava stillage or its anaerobic fermentation liquid as an external carbon source for BNR processes has considerable potential.

Table 5 Treatment performance of three SBRs as different carbon sources during the whole experimental period

\begin{tabular}{|c|c|c|c|}
\hline Parameter & SA & $\mathrm{CS}$ & CSF \\
\hline $\begin{array}{l}\text { Effluent COD } \\
(\mathrm{mg} / \mathrm{L})\end{array}$ & $25.5 \pm 4.5$ & $36.2 \pm 3.5$ & $27.1 \pm 6.3$ \\
\hline $\begin{array}{l}\text { COD removal } \\
\text { efficiency (\%) }\end{array}$ & $91.5 \pm 1.5$ & $88.7 \pm 1.2$ & $91.4 \pm 3.7$ \\
\hline $\begin{array}{l}\text { Effluent } \mathrm{NH}_{4}^{+}-\mathrm{N} \\
\quad(\mathrm{mg} / \mathrm{L})\end{array}$ & $0.6 \pm 0.6$ & $0.4 \pm 0.4$ & $0.5 \pm 0.6$ \\
\hline $\begin{array}{r}\mathrm{NH}_{4}^{+}-\mathrm{N} \text { removal } \\
\text { efficiency (\%) }\end{array}$ & $96.0 \pm 4.0$ & $97.3 \pm 2.5$ & $96.5 \pm 3.0$ \\
\hline $\begin{array}{l}\text { Effluent TN } \\
\quad(\mathrm{mg} / \mathrm{L})\end{array}$ & $18.7 \pm 1.7$ & $13.8 \pm 2.1$ & $12.9 \pm 2.5$ \\
\hline $\begin{array}{l}\text { TN removal } \\
\text { efficiency (\%) }\end{array}$ & $62.6 \pm 3.5$ & $72.4 \pm 3.2$ & $73.2 \pm 2.6$ \\
\hline $\begin{array}{c}\text { Effluent TP } \\
(\mathrm{mg} / \mathrm{L})\end{array}$ & $2.50 \pm 0.49$ & $1.42 \pm 0.64$ & $1.82 \pm 0.42$ \\
\hline $\begin{array}{l}\text { TP removal } \\
\text { efficiency (\%) }\end{array}$ & $58.3 \pm 8.1$ & $74.1 \pm 10.8$ & $69.6 \pm 7.3$ \\
\hline
\end{tabular}

\section{Conclusions}

In this study, we investigated the performance of cassava stillage and its anaerobic fermentation liquid used as the external carbon source for BNR in anaerobic-anoxic-aerobic SBRs. Based on the results, the following conclusions may be drawn:

1. Cyclic studies indicated that the cassava stillage and its anaerobic fermentation liquid affected transformations of COD, nitrogen, phosphorus, PHA, and glycogen of the BNR process. During the whole experimental period, the use of cassava stillage and its anaerobic fermentation liquid showed better TN removal efficiency $((72.4 \pm 3.2) \%$ and $(73.2 \pm 2.6) \%)$, respectively, than that of an equivalent amount of sodium acetate $((62.6 \pm 3.5) \%)$. EBPR occurred when the reactors were fed with cassava stillage and its anaerobic fermentation liquid as the carbon sources. Sludge analysis demonstrated that the ratio of DPAO/PAO reached 62.6\% (Day 86) and 61.8\% (Day 65) using cassava stillage and its anaerobic fermentation liquid as the sole carbon source, respectively.

2. Based on measurements, the NURs of the cassava stillage (5.49-5.99 g N/(kg MLVSS·h)) and its anaerobic fermentation liquid $(6.63-6.81 \mathrm{~g} \mathrm{~N} /$ (kg MLVSS·h)) were similar to or higher than those of other industry wastewaters as external carbon sources.

3. The performance of the SBRs indicated that addition of the cassava stillage and its anaerobic fermentation liquid as the external carbon sources enhanced both TN and TP removals, while COD or $\mathrm{NH}_{4}{ }^{+}-\mathrm{N}$ removal was not significantly affected.

4. The results presented indicate that cassava stillage and its anaerobic fermentation liquid could be used as potential external carbon sources for BNR processes.

\section{Compliance with ethics guidelines}

Fan BU, Xiang HU, Li XIE, and Qi ZHOU declare that they have no conflict of interest.

This article does not contain any studies with human or animal subjects performed by any of the authors.

\section{References}

APHA (American Public Health Association), 1998. Standard Methods for the Examination of Water and Wastewater, 20th Ed. APHA, Washington, DC.

Bernet, N., Habouzit, F., Moletta, R., 1996. Use of an industrial effluent as a carbon source for denitrification of a high-strength wastewater. Appl. Microbiol. Biotechnol., 46(1):92-97. [doi:10.1007/s002530050788]

Cappai, G., Carucci, A., Onnis, A., 2004. Use of industrial wastewaters for the optimization and control of nitrogen 
removal processes. Water Sci. Technol., 50(6):17-24.

Chae, S.R., Lee, S.H., Kim, J.O., et al., 2004. Simultaneous removal of organic and strong nitrogen from sewage in a pilot-scale BNR process supplemented with food waste. Water Sci. Technol., 49(5-6):257-264.

Dubois, M., Gilles, K.A., Hamilton, J.K., et al., 1956. Colorimetric method for determination of sugar and related substance. Anal. Chem., 28(3):350-356. [doi:10.1021/ ac60111a017]

Fang, H.H.P., Zhang, T., Liu, Y., 2002. Characterization of an acetate degrading sludge without intracellular accumulation of polyphosphate and glycogen. Water Res., 36(13): 3211-3218. [doi:10.1016/S0043-1354(02)00027-1]

Henze, M., Harremoës, P., la Cour Jansen, J., et al., 1995. Wastewater Treatment: Biological and Chemical Processes. Springer Verlag, Berlin.

Hinojosa, J., Riffat, R., Fink, S., et al., 2008. Estimating the kinetics and stoichiometry of heterotrophic denitrifying bacteria with glycerol as an external carbon source. Proceedings of the 81st Annual WEF Technical Exhibition and Conference, Chicago, USA. Water Environment Federation, Alexandria, USA, p.274-288. [doi:10.2175/ 193864708788735556]

Kampas, P., Parsons, S.A., Pearce, P., et al., 2009. An internal carbon source for improving biological nutrient removal. Bioresour. Technol., 100(1):149-154. [doi:10.1016/j. biortech.2008.05.023]

Kuba, T., Murnleitner, E., van Loosdrecht, M.C.M., et al., 1996a. A metabolic model for biological phosphorus removal by denitrifying organisms. Biotechnol. Bioeng., 52(6):685-695. [doi:10.1002/(SICI)1097-0290(19961220) 52:6<685::AID-BIT6>3.0.CO;2-K]

Kuba, T., van Loosdrecht, M.C.M., Heijnen, J.J., 1996 b. Phosphorus and nitrogen removal with minimal COD requirement by integration of denitrifying dephosphatation and nitrification in a two-sludge system. Water Res., 30(7):1702-1710. [doi:10.1016/0043-1354(96)00050-4]

Lee, C.Y., Shin, H.S., Chae, S.R., et al., 2003. Nutrient removal using anaerobically fermented leachate of food waste in the BNR process. Water Sci. Technol., 47(1): 159-165.

Lemos, P.C., Serafim, L.S., Santos, M., et al., 2003. Metabolic pathway for propionate utilization by phosphorusaccumulating organisms in activated sludge: ${ }^{13} \mathrm{C}$ labeling and in vivo nuclear magnetic resonance. Appl. Environ. Microbiol., 69(1):241-251. [doi:10.1128/AEM.69.1.241251.2003]

Li, H.J., Chen, Y.G., Gu, G.W., 2008. The effect of propionic to acetic acid ratio on anaerobic-aerobic (low dissolved oxygen) biological phosphorus and nitrogen removal. Bioresour. Technol., 99(10):4400-4407. [doi:10.1016/j. biortech.2007.08.032]

Lim, S.J., Choi, D.W., Lee, W.G., et al., 2000. Volatile fatty acids production from food waste and its application to biological nutrient removal. Bioprocess. Eng., 22(6):543545. [doi:10.1007/s004499900109]
Lowry, O.H., Rosebrough, N.J., Farr, A.L., et al., 1951. Protein measurement with the Folin phenol reagent. J. Biol. Chem., 193(1):265-275.

Makinia, J., Drewnowski, J., Swinarski, M., et al., 2012. The impact of precipitation and external carbon source addition on biological nutrient removal in activated sludge systems - experimental investigation and mathematical modeling. Water Pract. Tech., 7(1). [doi:10.2166/wpt. 2012.011]

Monclús, H., Sipma, J., Ferrero, G., et al., 2010. Biological nutrient removal in an MBR treating municipal wastewater with special focus on biological phosphorus removal. Bioresour. Technol., 101(11):3984-3991. [doi: 10.1016/j.biortech.2010.01.038]

Monteith, H.D., Bridle, T.R., Sutton, P.M., 1980. Industrial waste carbon sources for biological denitrification. Progress Water Technol., 12(6):127-141.

Oehmen, A., Yuan, Z.G., Blackall, L.L., et al., 2005a. Comparison of acetate and propionate uptake by polyphosphate accumulating organisms and glycogen accumulating organisms. Biotechnol. Bioeng., 91(2):162-168. [doi: 10.1002/bit.20500]

Oehmen, A., Keller-Lehmann, B., Zeng, R.J., et al., 2005 b. Optimisation of poly- $\beta$-hydroxyalkanoate analysis using gas chromatography for enhanced biological phosphorus removal systems. J. Chromatogr. A, 1070(1-2):131-136. [doi:10.1016/j.chroma.2005.02.020]

Oehmen, A., Lemos, P.C., Carvalho, G., et al., 2007. Advances in enhanced biological phosphorus removal: from micro to macro scale. Water Res., 41(11):2271-2300. [doi:10. 1016/j.watres.2007.02.030]

Oh, J., Silverstein, J., 1999. Acetate limitation and nitrite accumulation during denitrification. J. Environ. Eng., 125(3):234-242. [doi:10.1061/(ASCE)0733-9372(1999) 125:3(234)]

Peng, Y.Z., Wang, X.L., Li, B.K., 2006. Anoxic biological phosphorus uptake and the effect of excessive aeration on biological phosphorus removal in the $\mathrm{A}^{2} \mathrm{O}$ process. Desalination, 189(1-3):155-164. [doi:10.1016/j.desal.2005. 06.023]

Pijuan, M., Casas, C., Baettrrza, J.A., 2009. Polyhydroxyalkanoate synthesis using different carbon sources by two enhanced biological phosphorus removal microbial communities. Process Biochem., 44(1):97-105. [doi:10. 1016/j.procbio.2008.09.017]

Quan, Z., Jin, Y., Yin, C., et al., 2005. Hydrolyzed molasses as an external carbon source in biological nitrogen removal. Bioresour. Technol., 96(15):1690-1695. [doi:10.1016/j. biortech.2004.12.033]

Rodríguez, L., Villasenor, J., Buendia, I.M., et al., 2007a. Re-use of winery wastewaters for biological nutrient removal. Water Sci. Technol., 56(2):95-102. [doi:10.2166/ wst.2007.477]

Rodríguez, L., Villasenor, J., Fernandez, F.J., 2007b. Use of agro-food wastewaters for the optimisation of the denitrification process. Water Sci. Technol., 55(10):63-70. 
[doi:10.2166/wst.2007.307]

Sage, M., Daufin, G., Gesan-Guiziou, G., 2006. Denitrification potential and rates of complex carbon source from dairy effluents in activated sludge system. Water Res., 40(14): 2747-2755. [doi:10.1016/j.watres.2006.04.005]

Swinarski, M., Mąkinia, J., Czerwionka, K., et al., 2009a. Comparison of the effects of conventional and alternative external carbon sources for enhancing of the denitrification process. Water Environ. Res., 81(9):896-906. [doi:10.2175/106143009X407438]

Swinarski, M., Mąkinia, J., Czerwionka, K., et al., 2009b. Industrial wastewater as an external carbon source for optimization of nitrogen removal at the "Wschód" WWTP in Gdańsk (Poland). Water Sci. Technol., 59(1): 57-64. [doi:10.2166/wst.2009.774]

Thomas, M., Wright, P., Blackall, L., et al., 2003. Optimisation of Noosa BNR plant to improve performance and reduce operating costs. Water Sci. Technol., 47(12): 141-148.

Wachtmeister, A., Kuba, T., van Loosdrecht, M.C.M., et al., 1997. A sludge characterization assay for aerobic and denitrifying phosphorus removing sludge. Water Res., 31(3):471-478. [doi:10.1016/S0043-1354(96)00281-3]

Wang, Y.Y., Geng, J.J., Guo, G., et al., 2011. $\mathrm{N}_{2} \mathrm{O}$ production in anaerobic/anoxic denitrifying phosphorus removal process: the effects of carbon sources shock. Chem. Eng. J., 172(2-3):999-1007. [doi:10.1016/j.cej.2011.07.014]

Zhou, Y., Pijuan, M., Zeng, R., et al., 2008. Free nitrous acid inhibition on nitrous oxide reduction by a denitrifyingenhanced biological phosphorus removal sludge. Environ Sci. Technol., 42(22):8260-8265. [doi:10.1021/es800650j]

\section{中文概要}

题 目: 木薯酒糟及其厌氧发酵液作为外加碳源强化城市 生活污水生物营养盐去除研究

目 的: 针对目前城市污水处理中普遍存在的进水碳源不 足引起的脱氮除磷效率不高的问题, 而大量具有
很高碳氮比 $(\mathrm{C} / \mathrm{N})$ 和可生物降解有机成分的食 品工业废水亟需处理的现状, 本文考察了木薯酒 精厂废水（木薯酒糟及其厌氧发酵液）分别作为 外加碳源资源化利用的可行性。

创新点: 对比考察了木薯酒糟及其厌氧发酵液分别作为碳 源对活性污泥系统脱氮除磷的影响, 为处理低 $\mathrm{C} / \mathrm{N}$ 比城市污水寻求廉价优质的外加碳源提供理 论依据。

方 法: 通过运行三组平行的厌氧/缺氧/好氧序批式活性 污泥反应器 (SBR), 以乙酸钠作为对比, 考察 木薯酒糟及其厌氧发酵液作为碳源对活性污泥 系统碳、氮、磷变化规律的影响, 并通过硝酸盐 利用速率 (NUR) 和厌氧-缺氧/好氧批次试验对 污泥特性进行分析。

结 论: (1) 在整个试验过程中, 与乙酸钠作为碳源相 比, 木薯酒糟及其厌氧发酵液在相同的运行条件 下取得了更高的总氮 ( TN ) 去除率, 分别为 $(72.4 \pm 3.2) \%$ 和 $(73.2 \pm 2.6) \%$, 高于乙酸钠的 $(62.6 \pm$ $3.5) \%$ 。NUR 试验结果表明, 木薯酒糟及其厌氧 发酵液污泥的反硝化速率分别为 5.49 5.99 g N/ (kg MLVSS·h)和 6.63 6.81 g N/(kg MLVSS·h), 与其他研究中报道的食品工业废水的反硝化速率 相当或略高。（2）以木薯酒糟及其厌氧发酵液作 为碳源的系统发生了显著的反硝化聚磷现象, 两 体系中的反硝化聚磷菌分别占总聚磷菌的 $62.6 \%$

（86 天）和 61.8\%（65 天）。（3）以木薯酒糟 上清液及其厌氧发酵液作为碳源的生物营养盐 去除 (SBR) 系统均取得了良好稳定的脱氮除磷 效果。在 BNR 工艺中投加木薯酒糟及其厌氧碱 性发酵液作为外加碳源, 不仅可以提高系统氮磷 去除效果, 还能解决这部分废水的处理问题, 是 一种很有潜力的替代碳源。

关键词: 生物营养盐去除; 外加碳源; 反硝化; 强化生物 除磷 